\title{
MR. JUSTICE CARDOZO AND THE LAW OF CONTRACTS
}

\begin{abstract}
A REVIEW of the consecutive opinions of any court is likely to A be a sad undertaking, sad for the reviewer and sad for the reader of his review. A series of opinions by a group of judges, taken consecutively and according to the " run of the mine," will not be found to be filled with many nuggets of gold. At least, they will not seem so to any single reader. His interest is restricted within fairly definite boundaries, determined by his own past experience and study. What single reviewer will stay awake as he thumbs the pages of cases listed under "Errors and Appeals," or under "Patents" in the Federal Supplement, or under the conglomerate of titles such as Negligence, Workmen's Compensation, Indians, Automobiles and Criminal Law? The fact that each and every case had intense interest for the two litigants, for the attorneys who represented them, and for the judges as well, is not enough to keep the reviewer awake; much less is his review likely to keep others awake.
\end{abstract}

How different is the task of a reviewer who studies the work of a single judge, further limiting himself to the opinions of that judge in cases within the field of the reviewer's own interest and experience. And if the selected judge is a Mansfield, a Holmes, or a Cardozo, the reviewer comes away with bags of rich ore, although it may still be refractory in nature and his skill may be inadequate to reduce its value into current literary coin.

The work of Cardozo in the field of contract law is found in at few more than one hundred opinions rendered in the New York Court of Appeals during a period of about eighteen years. It cannot be said that he made any extensive changes in the existing law of contract. To state the facts of the cases, the decision, and the reasoning of his opinion will not show the overthrow of old doctrine or the establishment of new. Instead, it will show the application of existing doctrines with wisdom and discretion; an

408 HARV.

426 YALE

cot. 56 
application that does not leave those doctrines wholly unaffected, but one that carries on their evolution as is reasonably required by the new facts before the court. When Cardozo is through, the law is not exactly as it was before; but there has been no sudden shift or revolutionary change. This is judicial evolution - judicial legislation, if you please, restricted, as Holmes once said, from " molar to molecular motion " and of an " interstitial " character. No one case, therefore, may be of exciting interest; and it can be given interest in this article only by liberal quotation, showing Cardozo's style, reasoning, and judicial method.

\section{Indefintte Contracts and Iatplied Pronises}

Cardozo's opinions on contract law demonstrate his instinct for a justice that is human and practical. Himself a master of expression, both graceful and exact, he knows also how to understand and interpret the language of contractors, graceless and inexact, abbreviated and elliptical though it be. There is clear genius in his filling of gaps, his finding of promises by implication where none was put into clear words, his discovery and enforcement of the directing purpose for which a contract was made, not permitting that purpose to fail by reason of vagueness in details.

Where an employee was promised a "fair share of the profits" in addition to a specified salary, Cardozo refused to agree with the majority that the agreement failed for indefiniteness and uncertainty, justifying a discharge without cause. True, the employee cannot be given damages for failure to pay this " fair share "without proving how much it is; but in any event he is entitled to his agreed salary for the agreed period. He suggests, in addition, that the plaintiff might be able to show that usage fixed a fair share at a definite percentage. ${ }^{1}$

I Varney v. Ditmars, 217 N. Y. 223, 233, 11 I N. E. \$22, S26 (Igr6).

It is not often that Cardozo must dissent in a contract case. It is others who dissent, and not infrequently; for Cardozo is molding the law to justice, not applying literal rules and definitions though the heavens fall. Only rarely does he fail to induce the assent of at least half of his brethren on the bench. Oceacionally he writes a concurring opinion; but the others concur in that, too.

Two similar cases are Von Reitzenstein v. Tomlinson, 349 N. Y. 60, 162 N. E. 584 (1928), holding that a promise of "an appropriate percentage" of accruing benefits,

57 COL.

YALE 427

HARV. 409 
A plaintiff ordered goods and the defendant accepted, both agreeing that the price was $\$ 3$.Io per box, but was to be " subject to change pending tariff revision." A tariff bill was then pending in Congress but was not passed until long after performance became due. The defendant repudiated the contract on the ground that the price was too indefinite for enforcement. The court held the contract valid. It means either that if there is a change of tariff, the bargain is off until a new price is agreed upon; or that if there is a change of tariff before delivery the extra cost of importation is to be added to the price. In either case the defendant is bound if, as here, no tariff change occurs. Cardozo thus writes: "Read the privilege of change with inflexible adherence to its form, and one turns it into nonsense. If the change of price, to be valid, must be declared while revision is still pending, no change may be permitted after the revision is accomplished, which is the very time of all when a change will be essential. To read the reservation thus is to rob it of its efficacy as an implement to be used in furtherance of a business purpose. In the transactions of business life, sanity of end and aim is at least a presumption, albeit subject to be rebutted. The defendant like the plaintiff supposed that in signing these documents it was doing something understood to be signifi-

while not itself enforceable, showed that the value of the services had not been liquidated at the stated wages; and Cohen \& Sons v. Lurie Woolen Co., 232 N. Y. I12, $I_{4}, I_{33}$ N. E. 370,372 (I92 I), where the buyer was given the "privilege to confirm more if the seller can get more." The court said: "We think the implication plain that the buyer is to fix the quantity, subject only to the proviso that quantity shall be limited by ability to supply. It is said the option does not state the time within which election is to be announced. We think a reasonable time is a term implied by law. It is said the option does not embody a statement of the price. We think a 'privilege to confirm more' imports a privilege to confirm at the price of the initial quantity."

In Sun P. \& P. Ass'n v. Remington P. \& P. Co., 235 N. Y. $338,342,139$ N. E. 470 (1923), Cardozo holds, somewhat surprisingly, that a written agreement for the salo of 16,000 tons of newsprint was too uncertain for enforcement. The price was fixed for the first four months. For the next twelve months, it was to be fixed by agreement, for periods also to be agreed on, "said price in no event to be higher than tho contract price charged by the Canadian Export Paper $\mathrm{Co}$. to the large consumers." Two judges dissented, finding this sufficiently definite for enforcement by the buyer at the Export Company's price. Was Cardozo less moved to cure defects in the work of the well-paid lawyers of two rich corporations? Of course, all paper actually delivered had been paid for.

4IO HARV. 
cant and serious. It not only accepted the plaintifi's order, but it asked the plaintiff to confirm the terms of the acceptance, and followed this with a cable of the order to its manufacturer abroad. Was it all sound and fury, signifying nothing? " ?

Just as promises that are indefinitely expressed can be made clear by a liberal process of interpretation, so also can entire promises be found by reading between the lines. Sometimes a promise is implied for the purpose of maintaining an action for its breach - a defendant's promise; sometimes it is implied for the purpose of making it operate as a consideration, so as to sustain an action on another promise. Where an agent expressly promised to serve for five years, the court was able to find an implied promise by the principal to employ for five years. "The law, in construing the common speech of men, is not so nice in its judgments as the defendant's argument assumes. It does not look for precise balance of phrase, promise matched against promise in perfect equilibrium. It does not seek such qualities even in written contracts, unless perhaps the most formal and deliberate, and least of all does it seek them where the words are chosen by the master under legal advice and accepted by the servant without the aid of like instruction. There are times when reciprocal engagements do not fit each other like the parts of an indented deed, and yet the whole contract . . . may be 'instinct with an obligation' imperfectly expressed." 3

If a promise by a principal can be implied for the purpose of enforcing it, so also can a promise by the agent be implied in order

2 Outlet Embroidery Co. v. Derwent Mills, 254 N. X. 179, I83, 172 N. E. 462, 463 ( 1930 ).

3 Moran v. Standard Oil Co., 2II N. Y. IS7, 197, 105 N. E. 217, 221 (1914). Cf. Sundstrom v. State of New York, 213 N. Y. 68, rc6 N. E. 924 (rgr4) (implied promise by the state not to make the construction of a canal more expensive by permitting leakage from a parallel canal, caused by lack of repair). But there is no implied promise by a client to his attorney that he will not discontinue a suit. Andrews v. Haas, $21_{4}$ N. Y. 255 , 108 N. E. 423 (1915). The acceptance of an assignment of a leasehold, "subject to" the landlord's claim for past rent, is not a promise to pay that claim. Schwartz v. Cahill, 220 N. Y. 174, I15 N. E. 45 I (1917). The existence of an entire contract between a parent corporation and its subsidiary will not be found by implication from facts that do not clearly require it, when the contract so found would be illegal. Berbey v. Third Avenue Ry., 244 N. Y. 84, I55 N. E. 58 (I926).

59 COL.

YAIE 429

HARV. 4II 
to serve as a consideration for an express promise by the principal. Lady Duff-Gordon promised her agent in writing that he should have the exclusive privilege of marketing her fashion designs. When sued for breach, she argued that the agent had made no return promise. The court thus replies: "It is true that he does not promise in so many words that he will use reasonable efforts to place the defendant's indorsements and market her designs. We think, however, that such a promise is fairly to be implied. The law has outgrown its primitive stage of formalism when the precise word was the sovereign talisman, and every slip was fatal. It takes a broader view today." 1

\section{The Doctrine of Consideration}

Surely the doctrine of consideration is one of the "elementary" doctrines of the common law, one that chiefly distinguishes the common law from its great rival, the civil law. Everyone knows that an informal promise is never binding without consideration. Everyone knows that in order to be sufficient " in the eye of the law," the consideration must be a "detriment" to the promisee. A great many know, too, that it must be a "legal detriment," not just any old kind of detriment. The revered Holmes thought he $\mathrm{knew}$ that consideration must be something that is requested and bargained for by the promisor, and that is given by the promisee in exchange for the promise. Did he not make the Massachusetts Supreme Court say: "Of course the mere fact that the promisee relies upon a promise, made without other consideration, does not impart validity to what before was void." "

4 Wood v. Lucy, Lady Duff-Gordon, 222 N. Y. 88, 90, 118 N. E. 214 (1917). To attain the same purpose, a promise by the plaintiff was found by implication in Allegheny College v. National Chautauqua County Bank, 246 N. X. 369, 159 N. E. I'3 (I927), discussed below.

5 Martin v. Meles, I79 Mass. II4, II6, 60 N. E. 397, 398 (xgor). Later, in Wisconsin \& M. Ry. v. Powers, I9r U. S. 379, 386 (1903), holding that a tax exemption law was not made unrepealable by the fact that a railroad had been built in reliance on it, Holmes caused the United States Supreme Court to say: "But the other clements are that the promise and the detriment are the conventional inducements each for the other. No matter what the actual motive may have been, by the express or implied terms of the supposed contract, the promise and the consideration must purport to be the motive each for the other, in whole or at least in part. It is not enough

4 I2 HARV. 
In view of all these ancient principles and elementary knowledge, it appears strange that the American Law Institute, in its Restatement of the Law of Contracts, dogmatically asserts that many informal promises are binding without consideration of any kind, ${ }^{\circ}$ that the sufficiency of consideration does not depend upon its being either a detriment to the promisee or a benefit to the promisor, ${ }^{7}$ and that it is not required to move from the promisee or to the promisor. ${ }^{8}$ It is true that the Institute adopts Holmes' definition of consideration; ${ }^{3}$ but it does its best to reduce the other requirements stated above to the scrap heap. It takes pains to construct an express rule that, under some circumstances, action by the promisee in reliance on the promise will make that promise binding, though it was made without any consideration at all. ${ }^{10}$

How can a body of scholars and judges and lawyers dare to make such dogmatic assertions! Partly, it may be, because of two opinions by Cardozo. And yet, in neither of them does he purport to abandon ancient principles or to make new law. ${ }^{11}$ He recognizes growth and change in doctrine; but the statement (or is it Restatement?) of new doctrine he leaves to others. His compass points to his guiding star of good faith in promises and justice in meeting expectations; and he holds to his course, laboring manfully to make the shifting winds of doctrine and the waves of sentiment aid him toward his goal.

In the earlier of these two cases, ${ }^{12}$ there was a written agreement,

that the promise induces the detriment or that the detriment induces the promice, if the other half is wanting."

- Restatextent, Contracts (I932) \$ \$5.

$7 I d$. at $\$ 8 \mathrm{r}$.

$8 I d$. at $\$ 75(2)$.

$9 \mathrm{Id}$. at $\$ 75$.

10 Id. at $\$ 90$.

11 Indeed, in McGovern v. City of New York, 234 N. Y. 377, I3S N. E. 26 (x923), and in the De Cicco case, infra note I2, he quotes from Holmes with apparent approval.

12 De Cicco v. Schweizer, 22 I N. Y. 43I, II7 N. E. So7 (I9I7). The transaction in this case has sometimes been described as a "marriage settlement." But there was no property conveyed, in trust or otherwise. There was merely a father's promise to his prospective son-in-law to pay an annuity to his daughter, the prospective bride. Possibly the father bargained with Count Gulinelli for the marriage; it is reasonably clear that the marriage occurred in partial reliance on the promise; and it is certain that the father meant to provide for the comfort and happiness of his daughter.

6 I COL.

YAIE $43 I$

HARV. $4 I 3$ 
in the Italian language, executed by the defendant Joseph Schweizer and his wife Ernestine, and Count Oberto Gulinelli. It recites that Miss Blanche Schweizer " is now affianced to and is to be married to " the said Count. After this recital and nothing more, it proceeds: "Now in consideration of all that is herein set forth the said Joseph Schweizer promises and expressly agrees by the present contract to pay annually to his said daughter Blanche, during his own life and to send her, during her lifetime, the sum of two thousand five hundred dollars." Joseph paid the annuity for twelve years and in the instant case was sued for the next installment, both the Count and his wife having assigned to the plaintiff De Cicco. The court rendered judgment for the plaintiff.

Was there any consideration for the promise of Joseph Schweizer? In the signed document, none is stated, other than the recital of a fact, the fact that Blanche " is now affianced to and is to be married to " the Count. This recital was true. The happy pair were engaged; and the wedding day was set. It appears that they were married just four days after Joseph made his promise. Apparently, it was argued that the " marriage " was the consideration; and the defendant urged its insufficiency on the ground that the marriage was no more than the performance of an already existing legal duty.

Looking at the words of the document alone, it is hard to believe that Joseph Schweizer was bargaining for anything. From our knowledge of certain international marriages, or from our reading of novels, we may suspect that the Count was indeed driving a bargain with Joseph. The document states nothing of the kind. Is it not unworthy of us to make the decision rest upon such a suspicion with such a basis? From the words of the document alone, it would be reasonable to believe that in making his promise Joseph was motivated and induced by his love for his daughter, his joy at her approaching marriage, and his desire to provide for her support. None of these inducements just stated would be a sufficient consideration at common law; they were not and could not be matters of bargain. It may be that they would be a sufficient causa, under the civil law, to support Joseph's promise. 
The court, however, says that the trial judge was justified in making the inference of a bargain. "Undoubtedly, the prospective marriage is not to be deemed a consideration for the promise unless the parties have dealt with it on that footing. Nothing is consideration that is not regarded as such by both parties. But here the very formality of the agreement suggests a purpose to affect the legal relations of the signers . . . . We cannot say that the promise was not intended to control the conduct of those whom it was designed to benefit. Certainly we cannot draw that inference as one of law." A sound conclusion, if the purpose is to enforce a promise that was reasonably relied on; not so convincing, if intended to show that Joseph was making a bargain.

Did the marriage in fact take place in reliance on Joseph's promise? Cardozo recites the circumstances, and says that from them "we may infer that at the time of the marriage the promise was known to the bride as well as the husband, and that both acted upon the faith of it." Again, he says: "That they neither retracted nor delayed is certain. It is not to be expected that they should lay bare all the motives and promptings, some avowed and conscious, others perhaps half-conscious and inarticulate, which swayed their conduct. It is enough that the natural consequence of the defendant's promise was to induce them to put the thought of rescission and delay aside." Surely, this is convincing. Does it also lend support to the Law Institute?

But, finally, was the marriage anything more than the performance of an existing legal duty, both on the part of the Count who was promisee and on the part of Blanche who was a donee beneficiary? Not a duty owed by them to father Joseph; they are not shown to have made any engagement with him to marry each other. It was a contractual duty of each to the other. The promisee, Count Gulinelli, was under a legal duty to Blanche, a third party, albeit one to whom the money was to be paid and who, equally with the Count, acted in reliance on the promise. Many earlier New York decisions had held that the performance by $A$ of his contract duty to $B$ is not a sufficient consideration for a new promise by $C$. Cardozo cites some of these decisions; he does not express disapproval of them or deny the rule on which they de- 
pend. But he now brings Blanche, the named beneficiary, into the picture. Her action, too, is bargained for, or is intended to be induced, or at all events has been in fact induced. The Count is under a duty to Blanche, and Blanche is under a duty to the Count; but together they are under a duty to nobody. Together, they are free to rescind. Neither one has threatened a wrongful breach; and they are not blackmailing Joseph into a donation..$^{\text {ta }}$ All this is true, indeed. Can the Law Institute be blamed for observing that almost as much can be said for practically all cases of performance of a contract duty owed to a third person? ${ }^{14}$ The promisee is always "free" to offer a rescission; and the third person is always free to assent thereto. Together, they are always free. To be sure, the consideration is not often marriage; and frequently the third person is not an intended beneficiary of the promise sought to be enforced.

No one can doubt the soundness of this decision. Cardozo's opinion demonstrates its justice, cites and weighs critically the literature of the topic involved, and lays a foundation for subsequent development away from any mechanical application of the pre-existing duty rule. ${ }^{10}$

13 Cardozo says: "The distinction between a promise by $\mathrm{A}$ to $\mathrm{B}$ to induce hitn not to break his contract with $\mathrm{C}$, and a like promise to induce him not to join with C in a voluntary rescission, is not a new one." Id. at 436,117 N. E. at 809 . It is not suggested in the opinion that Count Gulinelli was threatening to jilt Blanche, or even that the idea of a mutual rescission had occurred to any of the parties involved. The father might have been bargaining for the "marriage"; and marriage is an event that makes both jilting and rescission impossible. But it seems clear that the father was not consciously bargaining for either forbearance to jilt or forbearance to rescind.

14 "Consideration is not insufficient because of the fact . . . (d) that the party" giving the consideration is then bound by a contractual or quasi-contractual duty to a third person to perform the act or forbearance given or promised as consideration." RESTATEMIENT, CoNTRACTS (I932) $\$ 84$ (d).

15 It was this De Cicco case that led directly to Cardozo's lectures and other extrajudicial writings on jurisprudence. The present writer published an article discussing Cardozo's opinion, entitled Does Pre-existing Duty Defeat Considcration (Igr8) 27 YALE L. J.362. In the following year, Cardozo hesitatingly accepted an invitation to deliver the Storrs Lectures at the Yale Law School. These were published under the title The NaTURe of tre Judicial Process. As orally delivered, they were a triumph. As printed, they have become a classic.

Two other opinions by Cardozo discuss "moral obligation" as a reason for enforcement; but they involve statutory law and will not be reviewed at length hero. The performance by $A$ of his existing contract duty to $B$ is not a sufficient consideri4 I6 HARV. 
Ten years after the $D e$ Cicco case, the much litigated problem of charitable subscriptions was presented to the court. ${ }^{16}$ Mary Johnston subscribed $\$ 5,000$ to Allegheny College, payable after her death, directing that the fund should be known as the Mary $Y$. Johnston Fund and that its proceeds should be used to educate students preparing for the ministry. She paid $\$ r, 000$ of the sum while still alive; and the College accepted it. Later she gave notice of revocation. After her death, the College sued for the balance of $\$ 4,000$ and was given judgment. Cardozo again discusses the doctrine of consideration and the offshoot therefrom called "promissory estoppel."

The promise when first made was a promise of a gift for a specified purpose and was not then binding. It was held that it became binding, in accordance with the promissory estoppel doctrine, when the College received the part payment. Such receipt raised the implication of a promise to use the fund as Mary had directed. It was by reason of this receipt and implied promise that Mary became bound to pay the balance of her subscription. Thus the revocable promise of the subscriber was turned into an enforceable bilateral contract by applying the supposed doctrine of promissory estoppel.

This case forms part of the judicial basis for the rule of the American Law Institute stated in Section 90 of the Contracts Restatement; but it goes further than does the rule stated there.

tion for a new promise by $B$ to pay increased compensation. AIcGovern $v$. City of New York, 234 N. Y. 377, I38 N. E. 26 (r923) (this remains true in spite of increaced costs due to war conditions); see Restatesmirt, Contricts (r932) $\$$;. Some courts, however, hold otherwise. The New York court had to apply the state constitution, which expressly forbade "extra compensation" to public contractors.

Four years later in Shaddock v. Schwartz, 246 N. Y. 288 , 158 N. E. 372 (1927), Cardozo must have felt some satisfaction in applying a statute that authorized a city to pay claims that were morally but not legally due. Aiter the lowest bidder had erected a building, the city was enjoined from paying because of an irregularity in the form of his bid. The city council thereupon voted to pay the contract price as reasonable compensation. This recognition of a moral obligation by the council was held to be valid. "The taxpayer insists that it does not supply the basis for a moral obligation. . . . Its conception of good conscience is one of a justice unrelieved by tenderness or charity. . . . We think the council was not limited in its estimate of moral obligation to this Draconian severity."

16 Allegheny College v. National Chautauqua Bank, 246 N. Y. 369 , 159 N. E. 173 (I927).

65 COL.

YALE 435

HARV. 4I7 
The Institute says that a promise may become enforceable by reason of subsequent action or forbearance in reliance on the promise; it must be action or forbearance of a "definite and substantial" character; and the promisor must have had reason to foresee, when he made the promise, that such action or forbearance would be induced. The Institute does not use the expression "promissory estoppel "; and it does not suggest that a bilateral contract can be made by such a process. Nevertheless, the decision is consistent with the rule of the Institute, and it is a reasonable step in the advancement of the law.

Various phrases in the opinion make it appear that Cardozo, like innumerable others, thought that there is a " doctrine of consideration" that is definite in form and that has come down to us from . the past. He speaks of "the classic doctrine "; and after referring to certain decisions based on estoppel, he adds: "So long as those decisions stand, the question is not merely whether the enforcement of a charitable subscription can be squared with the doctrine of consideration in all its ancient rigor. The question may also be whether it can be squared with the doctrine of consideration as qualified by the doctrine of promissory estoppel."

The present writer has no criticism of the court's decision in this case; nor with the ground of the decision that a gratuitous promise to pay $\$ 5,000$ may become binding by the donee's subsequent receipt of one-fifth of the sum and implied promise to maintain it as a memorial fund. But he knows of no " classic doctrine," except as one is quoted in the opinion from the works of Mr. Justice Holmes; and that one is "classic" only because the man who composed and repeated it is Holmes. The present writer knows of no doctrine of consideration that ever was stated and applied with "ancient rigor." Instead, the doctrine is one that was totally unknown in early English law, one that started from nothing and was constructed case by case as reasons for enforcing informal promises were found. The instant decision marks one more step in that evolutionary process - in the development of a doctrine that is modern rather than "classic" and that has always been characterized by flexibility rather than by "rigor." If the definition and statement of doctrine by Holmes now bid fair to become classic and

4I8 HARV.

436 YALE

COL. 66 
rigorous in application, it will be chiefly because the American Law Institute has followed Holmes. But the Institute has also fashioned its reliance doctrine in Section 9o, in addition to several other classes of exceptions, expressly opening to the courts the possibility of enforcing promises without any consideration as "rigorously "defined.

\section{Conditions EXPREss and Iarplied}

The process of interpretation and implication of promises in order to determine whether or not a contract has been made is often difficult, calling for the artistry of a Cardozo that justice may not fail. As the chronological history of a contract transaction proceeds, the same process must continue, and often it is even more difficult. What meaning and application are to be given to the words of the parties? Granting that one made a promise and that we know the performance that it requires, must he perform it though the heavens fall? Was his promise made conditional, in express terms, on some fact or event; and, if not, should not his legal duty be held to be conditional by implication, or by construction of law, on grounds of equity and justice? For what reasons should the court come to the aid of the foolish contractor, who made a promise without taking care to qualify it by making it conditional? Is it not his own folly that he did not look into the future, observe the " march of nature," and protect himself against the costs and hardships that afterwards will bear down upon him? ${ }^{17}$

If, on the other hand, a contractor, because of his wide experience and that of his astute counsel, does look into the future, and qualifies his promise by making it conditional on so many factors that the foolish promisee gets little for his money, with what liberality shall the court use those flexible doctrines of waiver and estoppel?

It takes wide reading and experience to realize how completely

17 Bentham observed that the law, by processes of interpretation and construction has "thus ... . in every country ... supplied the shortsightedness of individuals, by doing for them what they would have done for themselies, if their imagination had anticipated the march of nature." 3 Works (1883) rgx.

67 COL.

YALE 437

HARV. 419 
our living law of contract depends upon the answers to questions such as these; how much depends upon the honor and good will of the contracting parties before taking them to court; and eventually what qualities of reason and common sense and understanding are required of the judge who must answer them. ${ }^{18}$ We may congratulate ourselves that our judges have these qualities in so high a degree, and that among them there has been a Cardozo.

In pursuance of a contract for the sale of moving picture films, an installment of the price amounting to $\$ 10,000$ became due on December 24th. It was not paid on that day. With no additional fact proved to justify his action, the seller repudiated the contract and on December 26 th sued for damages as for a total breach. It is said that "in contracts of merchants, time is of the essence"; also that time is always of the essence "at law," though not in equity. Did this justify the seller's precipitate action? Not so, held the court. ${ }^{10}$ It depends on what was to be done at the time in question; and on why it was not done and on the injury resulting and on other things. Cardozo puts it thus: "General statements abound that, at law, time is always of the essence. For some purposes this is still true. The vendor who fails to receive payment of an instalment the very day that it is due may sue at once for the price. But it does not follow that he may be equally precipitate in his election to declare the contract at an end. That depends upon the question whether the default is so substantial and important as in truth and in fairness to defeat the essential purpose of the parties. Whatever the rule may once have been, this is the test that is now prescribed by statute. The failure to make punctual payment may be material or trivial according to the circumstances. We must know the cause of the default, the length of the delay, the needs of the vendor, and the expectations of the vendee.

18 "You can always imply a condition in a contract. But why do you imply it? It is because of some belief as to the practice of the community or of a class, or because of some opinion as to policy, or, in short, because of some attitude of yours upon a matter not capable of exact quantitative measurement and therefore not capable of founding exact logical conclusions." Holmes, The Path of the Law (1897) Io HaRv. I. REv. $457,466$.

19 Helgar Corp. v. Warner's Features, 222 N. Y. 449 , II9 N. E. I13 (1918). 'The court applies the language of the Uniform Sales Act; and, of course, the New York court is a court of equity as well as of common law.

420 HARV.

438 YALE

cor. 68 
If the default is the result of accident or misfortune, if there is a reasonable assurance that it will be promptly repaired, and if immediate payment is not necessary to enable the vendor to proceed with performance, there may be one conclusion. If the breach is wilful, if there is no just ground to look for prompt reparation, if the delay has been substantial, or if the needs of the vendor are urgent so that continued performance is imperiled, in these and in other circumstances, there may be another conclusion. Sometimes the conclusion will follow from all the circumstances as an inference of law to be drawn by the judge; sometimes, as an inference of fact to be drawn by the jury."

Look, on the other hand, at a road building contract in which the State promised to pay a total of $\$ 355,000$ in monthly installments on engineer's estimates. The sum of $\$ 9,300$ became so payable. The State tried to pay by issuing a warrant on a county treasurer, who refused to honor it. The court held that the contractor was justified in abandoning the contract, saying: "The monthly payments were the fund from which the expenses of the work were to be met. The contractor could not go on if the fund was not supplied. The State may indeed have been entitled to a reasonable opportunity to provide the necessary moneys after the county treasurer's default. If it had sought such an opportunity when informed of the dishonor of the drafts, the contractor might have been in the wrong in adhering to a precipitate rescission. But that was not the State's position." 20

In a contract for the erection of a building for the total sum of $\$ 77,000$, the specifications required certain iron pipe to be of "Reading" manufacture. A subcontractor used " Cohoes" pipe, identical in quality. After completion, the final installment of the price was refused; the architect refused his certificate and ordered the substitution of "Reading" pipe. The trial court prevented the contractor from proving that the change was trivial and directed a verdict for the defendant. This was held error, even though the duty to make the last payment was expressly conditional upon the architect's certificate." "Substantial perform-

20 Anderson v. Hayes Const. Co., 243 N. Y. I40, I53 N. E. 28 (I926).

21 Jacob and Youngs v. Kent, 230 N. Y. 239, 129 N. E. 889 (192I). Three judges dissented.

69 COL. 
ance "was enough in the " eye of the law." When we consider that the architect ordered the tearing down of walls in a $\$ 77,000$ house in order to replace " Cohoes " pipe with "Reading," it seems obvious that the court is doing justice. Of course on the new trial, the defendant will have an opportunity to prove that there were other reasons for refusing the certificate and the money.

Probably no other reported case can be found in which the question of dependency of promises and of implied conditions of an owner's duty to pay is discussed with as much enlightened intelligence and charm of expression as we find here in Cardozo's opinion: "Considerations partly of justice and partly of presumable intention are to tell us whether this or that promise shall be placed in one class or in another. The simple and the uniform will call for different remedies from the multifarious and the intricate. The margin of departure within the range of normal expectation upon a sale of common chattels will vary from the margin to be expected upon a contract for the construction of a mansion or a ' skyscraper.' There will be harshness sometimes and oppression in the implication of a condition when the thing upon which labor has been expended is incapable of surrender because united to the land, and equity and reason in the implication of a like condition when the subject-matter, if defective, is in shape to be returned. From the conclusion that promises may not be treated as dependent to the extent of their uttermost minutiae without a sacrifice of justice, the progress is a short one to the conclusion that they may not be so treated without a perversion of intention. Intention not otherwise revealed may be presumed to hold in contemplation the rensonable and probable. If something else is in view, it must not be left to implication. There will be no assumption of a purpose to visit venial faults with oppressive retribution.

"Those who think more of symmetry and logic in the development of legal rules than of practical adaptation to the attainment of a just result will be troubled by a classification where the lines of division are so wavering and blurred. Something, doubtless, may be said on the score of consistency and certainty in favor of a stricter standard. The courts have balanced such considerations against those of equity and fairness, and found the latter to be the 
weightier. The decisions in this state commit us to the liberal view, which is making its way, nowadays, in jurisdictions slow to welcome it. Where the line is to be drawn between the important and the trivial cannot be settled by a formula. 'In the nature of the case precise boundaries are impossible.' The same omission may take on one aspect or another according to its setting. Substitution of equivalents may not have the same significance in fields of art on the one side and in those of mere utility on the other. Nowhere will change be tolerated, however, if it is so dominant or pervasive as in any real or substantial measure to frustrate the purpose of the contract. There is no general license to install whatever, in the builder's judgment, may be regarded as ' just as good.' The question is one of degree, to be answered, if there is doubt, by the triers of the facts and, if the inferences are certain, by the judges of the law. We must weigh the purpose to be served, the desire to be gratified, the excuse for deviation from the letter, the cruelty of enforced adherence. Then only can we tell whether literal fulfilment is to be implied by law as a condition."

On the measure of the damages for the contractor's minor breach, the opinion shows the same clear common sense. To apply the usual rule measuring the damages by the cost of completion in accordance with the contract would have defeated the purpose that the court was trying to serve. It would have resulted in a judgment for the cost of total rebuilding. "In the circumstances of this case, we think that the measure of the allowance is not the cost of replacement which would be great, but the difference in value, which would be either nominal or nothing. . . . The rule that gives a remedy in cases of substantial performance with compensation for defects of trivial or inappreciable importance has been developed by the courts as an instrument of justice. The measure of the allowance must be shaped to the same end."

Conditions precedent to a contractor's duty to render his promised performance can be voluntarily "waived" by him; or, his conduct may be such, when relied upon by the other party, that he is " estopped" from using the nonperformance of the condition as a defense. Such waiver and estoppel are often available in 
suits on insurance policies; ${ }^{22}$ knowledge of the facts by the company's agents will sometimes be imputed to the company - it can have knowledge in no other manner.

And even though an agent has promised not to enter into deals without the employer's assent and has agreed further that there shall be no waiver or alteration except by a signed writing, this does not deprive the employer of power to waive by oral assent. "Those who make a contract may unmake it. The clause which forbids a change may be changed like any other. The prohibition of oral waiver may itself be waived. . . . What is excluded by one act is restored by another. You may put it out by the door; it is back through the window. Whenever two men contract, no limitation self-imposed can destroy their power to contract again." 23

\section{JUdictal REMEDIES FOR BREACH}

It is the availability of judicial remedies that gives effectiveness to the system of contract law. Agreements may be better than the law of contract, for habit and the mores of honor often lead to performance when the law does not require it; but the law of contract is no better than its remedies, for it is by applying remedies that "law" is created. The body of the law - its flesh and blood and bones - consists of the sum-total of its judgments, decrees, and executions. These can be organized into a system by reason

22 Good health of the insured at the date of execution of the policy does not remain a condition of the insurer's duty, when its agents took the application and received the premiums from the insured while in a hospital. Bible v. John Hancock Mut. Life Ins. Co., 256 N. Y. 458 , 176 N. E. 838 (I93I). A promise to "waive the forfeiture" on certain conditions, made after the forfeiture is already complete, becomes enforceable after fulfillment of the conditions by the insured. And "satisfactory evidence of insurability" means evidence that would satisfy reasonable men. Thompson v. Postal Life Ins. Co., 226 N. Y. 363, 123 N. E. 750 (1919). But when a forfeited policy is " reinstated" in reliance on a false statement fraudulently made, knowledge of the facts by a local agent was not a "waiver" and did not prevent the policy from being voidable. "False representations and broken warranties are not so easily repaired." McCormack v. Security Mut. Life Ins. Co., 220 N. Y. 447, 456, 116 N. E. 74, 77 (1917). The time fixed for performance by one party ceases to be "of the essence" if the other party gives such an oral assurance or permits the delayed performance to continue. Brede v. Rosedale Terrace Co., 216 N. Y. 246 , I10 N. E. 430 (1915) ; Holden v. Efficient Craftsman Corp., 234 N. Y. 437, 138 N. E. 85 (1923).

23 Beatty v. Guggenheim Exploration Co., 225 N. Y. 380,122 N. E. 378 (1919).

424 HARV.

442 YALE

COL. 72 
of the uniformity that exists in high degree, by reason of the fact that precedent follows precedent. Without some degree of uniformity in the application of remedies, we could neither state nor "restate" a system of law - a book full of rules and principles and doctrines and standards.

If a great jurist has to deal constructively with those factors that must exist before a remedy is available — with such matters as assent and consideration and conditions precedent - so also must he deal with the choice of remedy that is granted, with the measurement of damages, the limitations on specific enforcement, the meaning and extent of restitution.

Cardozo's work in these fields is of a piece with his work in the others. Against one who is guilty of a breach of contract, what are the limits of recovery? Must he pay for all the harms that are subsequent to his wrong, regardless of time and space? It is easy to say that relief is limited to compensation for harm caused by the breach; but causation is a mystery, and compensation is possible only in accordance with that elusive variable called valuation. For a practical working rule with which to start, Cardozo is content, like other judges, with the rule in Hadley v. Barendalc - a rule derived directly from the French, and doubtless indirectly from much earlier sources. He knows that it is not perfection, and that it does not give an automatic answer. But it served to keep a wireless company from having to pay $\$ 6,675$ to a plaintiff who would have earned that much as freight had his code message been sent to Manila. ${ }^{24}$ The company could not translate the code and could foresee nothing of the loss of business. Cardozo respects precedent and applies the rule. He writes: "We are not unmindful of the force of the plaintiff's assault upon the rule in Hadley $\boldsymbol{~}$. Baxendale in its application to the relation between telegraph carrier and customer. The truth seems to be that neither the clerk who receives the message over the counter nor the operator who transmits it nor any other employee gives or is expected to give any thought to the sense of what he is receiving or transmitting. This imparts to the whole doctrine as to the need for notice

24 Kerr Steamship Co. v. Radio Corp. of America, 245 N. Y. 284,157 N. E. 140 (Ig27).

73 COL.

YALE 443

HARV. 425 
an air of unreality. The doctrine, however, has prevailed for years so many that it is tantamount to a rule of property."

The value of the promised performance and of the harm suffered must be proved with some reasonable degree of accuracy; ${ }^{25}$ but this does not mean mathematical exactness or certainty. In the rare case in which a master sues his servant for abandonment, the measure is the value of the promised service less the agreed wages that are saved to the master; and the terms of a new contract made by the servant with another master are evidence of value sufficient to justify a substantial verdict. ${ }^{20}$ Interest may be allowed as damages, even where the claim was unliquidated; but if the full amount demanded by the claimant is allowed by the court, the interest may run from date of the demand, while if the claim was excessive, interest runs only from the date of bringing suit. ${ }^{3 t}$

Is there a "duty" on the injured party to avoid loss and mitigate damages? No, replies Cardozo, in an action by servant against master for wrongful discharge. ${ }^{28}$ "The final question is this: Does a servant's refusal to accept other employment amount to an extinguishment of liability for damage actually suffered, or to disproof of the claim that damage to the extent demanded was actually suffered? Plainly, I think, the latter. . . . The obligation of the master is merely to pay whatever damages have actually been suffered, and these exclude damages that a servant, acting reasonably, would have diminished or avoided. ... The statement is not infrequently made in treatise and decision that a

25 Broadway Photoplay Co. v. World Film Corp., 225 N. Y. 104, 12 I N. E. 756 (IgIg). Damages for failure to supply "first run" feature pictures to a theater cannot be awarded on a mere showing that the receipts from "first run" pictures are better than those from "second run." "The difference, however, was not constant, or even approximately constant. It was subject to the widest fluctuation. Quality counts, it seems, with pictures as with plays. . . . In this business, as in others, there are times when merit triumphs over novelty." Id. at $108,121 \mathrm{~N}$. I. at 757.

26 Triangle Waist Co. v. Todd, 223 N. Y. 27,119 N. E. 85 (1918).

27 Prager v. New Jersey Fidelity \& P. G. Ins. Co., 245 N. Y. 1, 156 N. E. 76 (I927). Of course, other variations in the allowance of interest are permitted to the courts.

28 McClelland v. Climax Hosiery Mills, 252 N. X. 347, 354, 169 N. E. 605, 608 (1930) (concurring opinion).

426 HARV. 
servant wrongfully discharged is ' under a duty' to the master to reduce damages, if he can. The phrase is accurate enough for most purposes, yet susceptible of misunderstanding, if emphasized too sharply (A. L. I. Contracts Restatement, Sec. 336). The servant is free to accept employment or reject it according to his uncensored pleasure. What is meant by the supposed duty is merely this, that if he unreasonably reject, he will not be heard to say that the loss of wages from then on shall be deemed the jural consequence of the earlier discharge. He has broken the chain of causation, and the loss resulting thereafter is suffered through his own act."

The law of specific enforcement is only slightly touched in Cardozo's opinions, although with a sure hand and with results open to no criticism. ${ }^{29}$ The cases are more numerous in which the remedy of restitution is considered - restitution as an alternative remedy for breach of contract, ${ }^{30}$ or for fraud ${ }^{32}$ or mistake ${ }^{32}$ connected therewith. A plaintiff who asks for restitution instead of damages is treated as having rescinded the contract; and if he has received a part performance of value he must restore it, or its value if it has any. This does not mean that the plaintif must restore what others, who conspired with the defendant in the fraud, have received. "The refusal of the conspirators to join in the undoing of the wrong may not be used as an excuse by partners in their guilt to keep the wrong alive. Equity is not crippled at such times by an inexorable formula. In exacting the return of

29 Two cases of interest are: Catholic Foreign ifission Soc. v. Oussani, $215 \mathrm{X}$. Y. I, I09 N. E. 80 (I9I5) (specific performance will not be refused for lack of mutuality of remedy where the plaintiff waives the condition that had previously made that remedy unavailable against himself); Farmers' Loan \& Trust Co. v. Mortimer, 219 N. Y. 290, II 4 N. E. 389 (IgI6) (specific enforcement refused because of the interests of third persons).

${ }^{30}$ Richard v. Credit Suisse, 242 N. Y. 346,152 N. E. 110 (1926) (a bank failing to deliver Polish marks in Warsaw must repay the dollars paid for its promice in New York).

31 Marr v. Tumulty, 256 N. Y. 15, r75 N. E. 356 (1931); Schank v. Schuchman, 212 N. Y. 352, I06 N. E. I27 (Igr4); New York Bankers, Inc. v. Duncan, 257 N. Y. I60, I77 N. E. 407 (193I).

32 Wayne County Produce Co. v. Duffy-1Mott Co., 244 N. Y. 351, 155 N. E. 669 (I927).

75 coL.

YALE 445

HARV. 427 
benefits as a condition of rescission it proportions the exaction to the justice of the case before it." 33

The remedy of restitution is sometimes described as quasi-contractual, and it is said to be based on equity and good conscience. But talk of "equity and good conscience" in a suit for " rescission" does not prove that the remedy was originally in equity rather than at common law. "The semblance of an action in equity rather than one at law has thus been given to their pleading. We speak of its form in that regard as a semblance, for we think it is nothing more." The relief asked was nothing more than money back. ${ }^{34}$

Further, calling the remedy quasi-contractual does not disconnect it with the contract. Where an artist died before completion of his personal service contract, his executrix was held to have a right to reasonable value of work done. The contract itself plays a large part in determining the amount of this recovery, even though it made no provision for the event of death. "The award will then conform to the principles of liability in quasi-contract and to the considerations of equity and justice by which that liability is governed. In either event the controversy is one that has its origin in the contract and in the performance of the work thereunder, just as much as if the work had been completed under a contract silent as to price, and the controversy had relation to the reasonable value. Death of the contractor has not nullified the contract in the sense of emancipating the claimant from the restraint of its conditions. They limit her at every turn. She cannot stir a step without reference to the contract, nor profit by a dollar without adherence to its covenants. The interrupted work may have been better than any called for by the plans. Even so, there can be no recovery if the contractor wilfully and without excuse has substituted something else. The value proportionately distributed may be greater than the contract price. Even so, the price, and not the value, will be the maximum beyond which the judgment may not go. 'The recovery in such a case cannot exceed the contract price, or the rate of it for the part of the service

33 Marr v. Tumulty, 256 N. Y. 15, 21, 175 N. E. 356,357 (x931).

${ }^{34}$ Schank v. Schuchman, 212 N. Y. 352, 356, 106 N. E. 127, 128 (1914).

428 HARV.

446 YALE

COL. 76 
performed.' The question to be determined is not the value of the work considered by itself and unrelated to the contract. The question to be determined is the benefit to the owner in advancement of the ends to be promoted by the contract." 3 "

\section{Arbitration Agreemients and Public Policy}

The judgment or decree of a court is a judicial remedy. What shall we say of the award of an arbitrator? It, too, is a judicial remedy of a kind. An arbitrator is a judge in a dispute - indeed, he is both judge and jury. But he is one who is appointed by the litigating parties, or in a manner on which they have agreed; and he is appointed to serve for the one litigation only. He is not a public official whose power and duty it is to serve all comers. The ordinary litigant must take his chances before a public officer, chosen by others long in advance and without reference to a specific case. One who submits his case to an arbitrator selects his own judge; and he selects one, if he can induce the other party to agree, who is most likely to be prejudiced in his own favor.

If two parties agree to take their chances before an arbiter so selected, does the public interest require us to refuse the enforcement of that agreement? It has never been regarded as against public policy for two parties to agree, after a dispute has arisen, to submit that dispute to a private arbiter and to promise to abide by his decision. The judicial remedies available for the enforcement of such an agreement, however, were not very effective. The amount of harm caused by one party's refusal to arbitrate is always too uncertain and difficult of proof to make a judgment for damages effective; and the courts of equity were unwilling to try to enforce the agreement specifically. Nevertheless, if the arbiter was duly appointed, gave a fair hearing and rendered an award, that award was conclusive and was enforceable in the courts.

On the other hand, for reasons not wholly free from obscurity and uncertainty, the courts held that an agreement by two parties, made on entering into a transaction and before any dispute has (I930).

${ }^{35}$ In re Buccini v. Paterno Const. Co., 253 N. Y. 256, 25S, 170 N. E. 910, grI 
arisen, that they will submit all disputes thereafter arising to arbitration, to the exclusion of the courts, is contrary to public policy and void. It may be observed here that if one of the parties to such a contract has greater economic or mental bargaining power than the other, he gets a double advantage therefrom, the advantage of favorable terms and the advantage of a favorable judge. This will be illustrated by the first case of the kind that came before Cardozo.

An attempt, previously successful in the English courts, was made to avoid the effect of this doctrine of public policy. The advance agreement providing for the arbitration of all future disputes was drafted so as to declare that it was not intended to " oust the courts of jurisdiction," but only to determine the substantive rights of the parties. It was provided that if a dispute should thereafter arise, neither party should have an enforceable right until after arbitration was held as agreed and an award rendered. This made an award a condition precedent to any right of action. Surely the law recognizes freedom of contract and the power of two contracting parties to control their substantive rights and duties, even though they cannot control judicial remedies or deprive the courts of jurisdiction over the enforcement of rights and duties after they come into existence. In case of dispute, the only right that either party has is a right to the performance of an award after it shall be rendered. As soon as such a right is born, let the courts enforce it by such remedies as they will. Before the award, there is no right or duty for the courts, or anybody else, to enforce. Such was the argument; and its cogency was supported by the fact that many had doubts that any arbitration agreement was contrary to public policy.

Within Cardozo's first year on the bench, a contract providing in advance for general arbitration came before him. ${ }^{a 6}$ A railroad construction contract made the chief engineer of the railroad company " arbitrator to decide all matters in dispute arising out of the contract ... and each party hereby waives all right of action, suit or suits or other remedy . . . to enforce any claim except as the same shall have been determined by said arbitrator." The trial

36 Meacham v. Jamestown, F. \& G. R. R., 2 II N. Y. 346, 105 N. E. 653 (1914).

430 HARV.

448 YALE

COL. 78 
court held this contract valid and that no action would lie before an award, for the reason that the award of the engineer was made a condition precedent to any right of action. The opinion of the Court of Appeals, written by Judge Hogan, did not refer to this reason, but it held that the agreement attempted to oust the courts of jurisdiction and was against public policy and void.

Cardozo appears to have had no doubts as to the correctness of the decision, but he thought that the court should express its disapproval of the condition precedent argument. In a concurring opinion, he says: "If an agreement that a foreign court shall have exclusive jurisdiction is to be condemned, it is not saved by a declaration that resort to the foreign court shall be deemed a condition precedent to the accrual of a cause of action. A rule would not long survive if it were subject to be avoided by so facile a device. Such a contract, whatever form it may assume, affects in its operation the remedy alone..$^{37}$. . . If any exceptions to the general rule are to be admitted, we ought not to extend them to a contract where the exclusive jurisdiction has been bestowed, not on the regular courts of another sovereignty, but on private arbitrators. Whether the attempt to bring about this result takes the form of a condition precedent or a covenant, it is equally ineffective."

Not many years later, the New York Legislature passed the arbitration statute that nullifies this decision, making arbitration agreements valid and enforceable, whether general or limited in scope and whether in form of condition precedent or covenant. It provides for a court order suspending any action until the arbitration agreed on shall be held.

Soon, another arbitration case came before Cardozo and his court. $^{38}$ The new arbitration statute was held constitutional and

37 There may be error in this statement that such a contract "afiects in its operation the remedy alone "; but there is no doubt that it affects remedy, in addition to the rights for which remedies exist. But if $A$ contracts to pay, for construction work done by $B$, the amount of money at which $C$ shall appraise the work done, the appraisal by $C$ is a condition precedent to $A$ 's right to payment. Under the contract, there is no right in $B$ and no duty in $A$ requiring the payment of any money before $C$ appraises; and after his appraisal, the only right is a right to the payment of the sum so fixed. Surely, this affects the right as well as the remedy.

38 In re Berkovitz v. Arbib \& Houlberg, 230 N. Y. 261, 130 N. E. 2SS (1931).

79 cor.

YAIE 449

FARV. $43 I$ 
valid. When it was argued that the statute impairs the obligation of a contract, Cardozo retorted: "There is no merit in the contention. The obligation of the contract is strengthened, not impaired." He held that the statute affects remedies, not substantive rights, notwithstanding their inseparable nature; the statute is therefore applicable to contracts made before the statute was passed, although it will not be applied to nullify results already reached in existing litigation.

It was argued that the statute ousted the courts of jurisdiction, contrary to the state constitution. He replied: "Jurisdiction exists that rights may be maintained. Rights are not maintained that jurisdiction may exist. The People, in establishing a Supreme Court to administer the law, did not petrify the law which the court is to administer." He finds no deprivation of jurisdiction, since the court is now merely required to enforce a contract as made, instead of setting it aside. Cardozo makes no critical reference to the Meacham decision, but he pays scant respect to the notions of public policy on which that decision was founded. "The ancient rule, with its exceptions and refinements, was criticized by many judges as anomalous and unjust. It was followed with frequent protest, in deference to early precedents. Its hold even upon the common law was hesitating and feeble. We are now asked to declare it so imbedded in the very foundations of our jurisprudence and the structure of our courts that nothing less than an amendment of the Constitution is competent to change it. We will not go so far. The judges might have changed the rule themselves if they had abandoned some early precedents, as at times they seemed inclined to do. They might have whittled it down to nothing, as was done indeed in England, by distinctions between promises that are collateral and those that are conditions. No one would have suspected that in so doing they were undermining a jurisdiction which the Constitution had charged them with a duty to preserve. Not different is the effect of like changes when wrought by legislation."

\section{Statute of Frauds, and Parol Evidence Rule}

Cardozo found ample opportunity to display his instinct for justice, and his skill and common sense as an interpreter, in deal- 
ing with cases involving the Statute of Frauds and the parol evidence rule. The Statute itself is content with " some note or memorandum " of the contract; so is Cardozo. The memorandum must indeed be signed ${ }^{30}$ and it must truly represent the agreement in fact made; ${ }^{10}$ but if liberality of interpretation and implication is permitted in the case of written contracts, even more should be permitted in case of a " note or niemorandum."

In settling a disagreement, the defendant signed a writing to the effect that "the arrangements made for employment of Marks in our business . . continue in force until Jan. I, rgr6." Salary was stated; but nothing was said as to the service to be rendered by Marks. This was held to be a sufficient memorandum of the contract to satisfy the Statute of Frauds. It purports' to continue an existing employment. What that employment was can be shown by oral evidence of the actual performances, as well as by previous writings, even though not referred to. "In thus identifying the position we are not importing into the contract a new element of promise. We are turning signs and symbols into their equivalent realities. This must always be done to some extent, no matter how many are the identifying tokens. 'In every case, the words must be translated into things and facts by parol evidence.' How far the process may be extended is a question of degree. We exclude the writing that refers us to spoken words of promise. We admit the one that bids us ascertain a place or a relation by comparison of the description with some ' manifest, external, and continuing fact.' The statute must not be pressed to the extreme of a literal and rigid logic. Some compromise is inevitable if words are to fulfil their function as symbols of things and of ideas. How many identifying tokens we are to exact, the reason and common sense of the situation must tell us." 11 Hence, it was held that the

39 Mesibov, Glinert \& Levy v. Cohen Bros. IIfg. Co, 245 N. Y. 305, 157 N. E. I48 (Ig27) (printed name at top of an order blank held not to be a cignature).

40 N. E. D. Holding Co. v. McKinley, 246 N. Y. 40,157 N. E. 923 (1927). A signed memorandum was on a stereotyped form, with some of the blanks unfilled. No time was stated for conveyance or for the final payment. The court was willing to supply these gaps by making inferences, in the absence of a showing that the parties otherwise espressly agreed. "The parties evidently thought they were bound, for they described the writing as a binder. We are not to strain for a construction that will defeat their expectation." Id. at 44,157 N. E. at 924.

11 Marks v. Cowdin, 226 N. Y. 138, 143, I23 N. E. 139, I41 (19r9).

8 I COL. 
plaintiff could introduce evidence of the service that he had previously been performing, that he had been in fact " sales-manager" with definite powers and duties.

A contract that is required to be in writing by the Statute, and is in writing, may be modified by a subsequent oral agreement, if the contract as thus modified is one that the Statute does not require to be in writing. ${ }^{42}$ If the contract as orally modified is one that is within the Statute, it is not enforceable by action; yet if it is reasonably relied on by the plaintiff, a vendor, so that he delays in clearing his title as required by the written contract, the purchaser is not justified in repudiating the contract by reason of that delay. $\mathrm{He}$ is estopped from taking advantage of a nonperformance of condition that he himself induced by making the oral agreement. In a concurring opinion, Cardozo writes: "The principle is fundamental and unquestioned. Sometimes the resulting disability has been characterized as an estoppel, sometimes as a waiver. We need not go into the question of the accuracy of the description. The truth is that we are facing a principle more nearly ultimate than either waiver or estoppel, one with roots in the yet larger principle that no one shall be permitted to found any claim upon his own inequity or take advantage of his own wrong. The Statute of Frauds was not intended to offer an asylum of escape from that fundamental principle of justice." 13

In a case dealing with the "part performance" doctrine, ${ }^{44}$ Cardozo shows his willingness to adhere to existing New York prec-

42 Lieberman v. Templar Motor Co., 236 N. Y. 139 , 140 N. E. 222 (1923). A written contract that could not be performed within one year was modified orally at a time when the modified contract could be performed within one year. Many courts have carelessly said the contrary.

43 Imperator Realty Co. v. Tull, 228 N. Y. $447,457,127$ N. E. 263,266 (1920).

44 Burns v. McCormick, 233 N. Y. 230, I35 N. E. 273 (1922). This follows Maddison v. Alderson, 8 App. Cas. 467 ( $\left.188_{3}\right)$, and the decision, on the exact facts of the case, is in harmony with Restatement, Contracts (1932) 3 I97. There are many cases in other states that are contra. A judgment for the reasonable value of his services was available to the plaintiff; and it was probably not a seriously inadequate remedy, for the reason that the plaintifi's change of position was not very great. Even so, Cardozo should have given critical thought to the doctrine that the part performance must be "solely and unequivocally referable" to the contract sought to be enforced. That doctrine is practically unworkable. Competent scholars generally disapprove it, and the American Law Institute does not adopt it. 
edents and to accept the policy of the Statute as declared by the legislature. At the request of an old man, the plaintiff gave up a small business, moved to the promisor's home, and there cared for him until he died - all in reliance on the old man's oral promise to leave the land to the plaintiff at death. It was held that this was not such " part performance " as made the oral promise specifically enforceable. The court says: "We hold, then, that the acts of part performance are not solely and unequivocally referable to a contract for the sale of land. . . . We do not ignore decisions to the contrary in other jurisdictions. They are not law for us. Inadequacy of legal remedies, without more, does not dispense with the requirement that acts, not words, shall supply the framework of the promise. . . . The peril of perjury and error is latent in the spoken promise. Such, at least, is the warning of the Statute, the estimate of policy that finds expression in its mandate. Equity, in assuming what is in substance a dispensing power, does not treat the Statute as irrelevant, nor ignore the warning altogether. It declines to act on words, though the legal remedy is imperfect, unless the words are confirmed by deeds. A power of dispensation, departing from the letter in supposed adherence to the spirit, involves an assumption of jurisdiction easily abused, and justified only within the limits imposed by history and precedent. The power is not exercised unless the policy of the law is saved." 4

The "parol evidence rule " represents an effort by the courts to attain the same general purpose underlying the Statute of Frauds - the prevention of successful fraud and perjury. The Statute attempts to attain that purpose by declaring that certain oral contracts shall not be enforceable by action; the parol evidence rule, by declaring that a contract, when once integrated in writing, shall not be varied or contradicted by testimony of antecedent oral agreements and understandings. Both the Statute and the rule, if they attain their end at all, attain it at heavy cost to many honest men; they prevent the enforcement of many agreements that were in fact made, and sometimes cause the enforcement of an agreement that was not in fact made. Such a result as this was certainly not within the purpose of either the Statute or the rule; and in innu-

45233 N. Y. at 234,135 N. E. at 274 .

83 COL.

YALE 453

HARV. 435 
merable cases the courts have avoided such a result by manhandling both. Read a thousand cases in which oral contracts have been held to be enforceable by devices said to take them " out of the Statute," and that legislative act takes on the aspect of a living skeleton. Read a like number of cases in which oral testimony has been admitted to vary and explain writings, and the parol evidence rule assumes the semblance of a ghostly fiction. Yet at other times, both are vigorously supported and are applied with apparent disregard of the merits of the specific case.

In such of Cardozo's opinions as might involve the parol evidence rule, he does not actually apply it. He welcomes and requires the admission of oral testimony as to the antecedent negotiations and surrounding facts, in order to aid him in determining the expressed intent of the parties, what they in fact said and what its meaning. Often he is willing to leave the issues to the jury. ${ }^{40}$ of course, the meaning that will determine legal effect is that which is arrived at by objective standards; one is bound, not by what he subjectively intends, but by what he leads others reasonably to think that he intends. ${ }^{47}$ But in finding this meaning, evidence should be admitted with great liberality to aid the court and jury in understanding and interpreting; ${ }^{48}$ evidence should be admitted " showing forth the transaction in all its length and breadth."

46 See Saltzman v. Barson, 239 N. Y. 332, 146 N. E. 618 (1925); Loomis v. New York C. \& H. R. R. R., 214 N. Y. 447 , 108 N. E. 837 (1915).

47 U. S. Rubber Co. v. Silverstein, 229 N. Y. $x 68,128$ N. E. 123 (1920). "The promise, if uncertain, was to be taken in the sense ' in which the promisor had reason to suppose it was understood by the promisee." Id. at 171,128 N. E. at 124.

48 See Utica City Nat. Bank v. Gunn, 222 N. Y. 204, 208, IIS N. E. 607, 608 (I9r8), holding that a written guaranty, couched in words that seemed to make it applicable only to new loans made thereafter, was shown by cvidence of extrinsic facts to be applicable to an existing loan and to renewals thereof. It was a four-tothree decision; and Cardozo admits that the strict legal meaning of the words would cover only future loans and discounts. He says: "The proper legal meaning, how. ever, is not always the meaning of the parties. Surrounding circumstances may stamp upon a contract a popular and looser meaning. . . . To take the primary or strict meaning is to make the whole transaction futile. To take the sccondary or loose meaning is to give it efficacy and purpose. In such a situation, the gencis and aim of the transaction may rightly guide our choice. . . . Verbal niceties might yield in their minds [the "triers of the facts "] to the overmastering consideration that unless related to past loans, the obligation of the bond was a vain and empty form. It is easier to give a new shade of meaning to a word than to give no meaning to a whole transaction."

436 HARV. 
The words last quoted are from a very interesting case. ${ }^{43}$ Both parties asserted that a contract had been consummated; but they disagreed as to its terms. A written document had been executed by both parties, providing for amounts and prices of labor and materials, but somewhat cryptic in form. The trial judge ruled that this document was as matter of law a contract, and excluded all conversations at the time of signing and before. He held for the plaintiff, leaving only the assessment of damages to the jury. The Appellate Division ruled that as matter of law there was no contract and dismissed the complaint.

The Court of Appeals held that both lower courts were in error. Having considered the document, the pleadings, and the oral and written testimony, Cardozo held that it was not for the court to decide, as "matter of law," either that the transaction had never passed beyond the stage of preliminary negotiation, or that the document in evidence constituted a final and complete integration of the agreement. That decision must be made as one of fact, after admitting all relevant testimony " showing forth the transaction in all its length and breadth." This testimony might show that the delivery of the document had been subject to some extrinsic condition; also that some related matters had been reserved by the parties for future consideration. There may have been no contract; there may have been a contract partly oral and partly in writing; there may have been a fully integrated written contract. As one of these alternatives, the jury might adopt the third and find that there was a written integration, complete and final in every respect; but they can so find only after hearing and weighing a mass of conflicting parol testimony. If they so find, it would seem that this written integration makes inadmissible the very testimony that the jury had to weigh in order to determine the character of the document that made it admissible.

\section{The "Judiclat Process" of Cardozo}

The work of Cardozo in contract cases does not demonstrate the existence of very unusual ability in the analysis of complex problems and transactions. His great strength is demonstrated as

${ }^{49}$ Saltzman v. Barson, 239 N. Y. 332, 336, I46 N. E. 618, 619 (1925).

85 coL.

YALE 455

HARV. 437 
an interpreter of human conduct and expression and as a minister of justice. Being blest with an understanding of the purposes of contractors, he translates their defective words and symbols into a language that is clear to all. Blest with a familiarity with the literature of the law, he makes the happiest use of it. Blest with an understanding of human justice, its expression in judicial opinions, and its basis in the prevailing but sometimes changing mores and practices of men, he leads his court so as to administer that justice, never letting traditional dogma or commonly-stated doctrine block its attainment. Thus he molds doctrine without repudiating it. In his judicial process, Cardozo draws from the very wellsprings and fountainheads, and pours forth the living draught in a liquid style that sparkles with his own incomparable charm and personality.

All this does not mean that Cardozo is building a new system of contract law. No one knows better than he that even a Cardozo can do no such thing. ${ }^{50} \mathrm{He}$ is making an existing system work

50 In this article it has not been attempted to consider all of the cases in which Cardozo wrote an opinion. The New York law of third-party beneficiarles is long, complicated, and inconsistent. Cardozo's opinions do not go far toward making it less so. See the following cases: American Ex. Nat. Bank v. Goubert, 2 ro N. Y. $42 \mathrm{I}$, I04 N. E. 928 (I914) (holding a bond to be one for the indemnity of the promisee alone); Farnsworth v. Boro Oil \& Gas Co., 216 N. X. 40, 109 N. E. 860 (rg15) (enforcing, in a suit by a citizen, a promise made to his town by a public service corporation); Kottler v. New York Bargain House, 242 N. Y. 28,150 N. E. 59r (1926) (landlord can enforce a promise to pay the rent made by the orixinal tenant's assignee) ; Weatherwax v. Royal Indemnity Co., 250 N. Y. 281 , 165 N. E. 293 (1929), and Rushing v. Commercial Casualty Ins. Co., 25I N. Y. 302, 167 N. E. 450 (r929) (holding the beneficiary's right to be conditional as was the right of the promisee); Fosmire v. National Surety Co., 229 N. Y. 44, 127 N. E. 472 (1920) (denying, on somewhat debatable grounds, that a laborer can maintain suit on a contractor's surety bond expressly conditioned on payment of laborers). This last case was later distinguished and limited by Cardozo in Johnson Service Co. v. Monin, 253 N. Y. 417 , I7I N. E. 692 ( 1930 ), and in Strong v. American Fence Const. Co., 245 N. Y. 48,156 N. E. 92 (1928).

Two cases dealing with the law of accord and satisfaction are worthy of spccial note. In Gaston \& Co. v. Storch, 253 N. Y. 68, I70 N. E. 496 (1930), a claimant cashed a check stated on its face to be "in full settlement." This did not exclude testimony of the actual oral agreement on which it was tendered and received. In Hudson v. Yonkers Fruit Co., 258 N. Y. 168, 179 N. E. 373 (1932), Cardozo decided that where money was held in trust, no accord and satisfaction would result from the acceptance by the claimant of a part of the fund, tendered by the trustee as a full settlement, after deducting the amount of his disputed claim for scrvices rendered.

438 HARV.

456 YALE

COL. 86 
well in new cases as they arise. He is taking the past, indeed welllearned and well-respected, and molding it to serve the ends that it has always served. It is true that he does not leave it unaffected and unchanged in the process. So it has always been with other judges, great and small. Such is indeed the Nature of the Judicial Process.

In this process, are the judges breaking down an existing certainty of law and destroying the advising lawyer's golden dream of intellectual repose? Let us permit the great jurist to speak for himself. "I was much troubled in spirit, in my first years upon the bench, to find how trackless was the ocean on which I had embarked. I sought for certainty. I was oppressed and disheartened when $I$ found that the quest for it was futile. I was trying to reach land, the solid land of fixed and settled rules, the paradise of a justice that would declare itself by tokens plainer and more commanding than its pale and glimmering reflections in my own vacillating mind and conscience. I found "with the voyagers in Browning's " Paracelsus " that the real heaven was always beyond.' As the years have gone by, and as I have reflected more and more upon the nature of the judicial process, I have become reconciled to the uncertainty, because I have grown to see it as inevitable. I have grown to see that the process in its highest reaches is not discovery, but creation; and that the doubts and misgivings, the hopes and fears, are part of the travail of mind, the pangs of death and the pangs of birth, in which principles that have served their day expire, and new principles are born." $" 1$

Arthutr L. Corbin.

YaLe Schoor of Law.

51 The Nature of the Judicild Process (I92I) 166.

87 cor.

YALE 457

HARV. 439 